\title{
Ontologia \\ nienowoczesności \\ w poezji Piotra \\ Szewca
}

\author{
Marta Tomczok
}

ORCID: 0000-0001-9512-007X

\section{Anachronizm}

Wiersz Piotra Szewca Gorzkie żale, pochodzący z 2013 roku, przynosi sugestywny obraz polskiej wsi. Jest on na tyle przekonujący, że ma się wrażenie, jakby opisywane zdarzenia rozgrywały się w tej właśnie chwili, a oprócz nich nie działo się nic innego: nie wybuchały wojny, nie rodziły się dzieci, nie ginęły gatunki roślin i zwierząt, nie umierali ludzie. Istotne jest tylko to, że:

\footnotetext{
Myszy pogryzły makówki w spichlerzu pękają strąki sypie się fasola dziurawy dach przecieka z osiki lecą liście i kleją się do butów gdy przysiadamy na schodach sieni jakby wojsko czarne płyną gorzkie żale chleba naszego powszedniego zbierz jajka mówi babcia w zimnym deszczu krowy mokną drzemią nastroszone kury kot miauczy znajomo pyskuje sieczkarnia rzyga pociętą słomą przed zmierzchem zabłąkany gołąb szuka domu już odleciał krótki dzień oderwał się od kalendarza pospiesznie przeprawia się przez zaorane pola ${ }^{1}$.
}

\footnotetext{
${ }^{1}$ Piotr Szewc, „Gorzkie żale”, w Tymczasem. Wybór wierszy (Poznań: Wydawnictwo WBPiCAK, 2019), 51. O ile nie podano inaczej, wszystkie wiersze cytowane w artykule pochodzą z tego zbioru, oznaczanego symbolem „T”, pełnym tytułem utworu oraz odnotowaniem strony publikacji.
} 
W powyższym opisie uderza nagromadzenie zwykłych zajęć i rzeczy, ich nadmiar, przesadnie wyeksponowana praktyczność. Jeśli popatrzeć na nią nie jak na wadę tekstu, szczególnie wadę o charakterze estetycznym, lecz jak na sygnał odnowienia kategorii opisu, można by w Gorzkich żalach odnaleźć elementy koncepcji Tima Ingolda dotyczące tworzenia opowieści o materiałach ${ }^{2}$. Jak twierdzi brytyjski antropolog, naszą uwagę powinny zajmować przede wszystkim praktyczne historie rzeczy. „Aby opisać [podkreśl. M.T.] właściwości materiałów, należy opowiedzieć historię o tym, co się z nimi dzieje, gdy przepływają, mieszają się i mutują"3.

Polecenie „zbierz jajka”, wydane przez bohaterkę wiersza, babcię, znaczy tyle samo, co najważniejsze decyzje polityczne tamtego czasu. Jednocześnie - pozostańmy przy wrażeniach zaskoczonego czytelnika - nieco razi prostotą, dziwi gwałtownością odwrotu od ważnych problemów nowoczesności, irytuje niczym zachowanie nie na miejscu. Dlaczego w ogóle polecenie „zbierz jajka” miałoby kogokolwiek obchodzić? Po co znalazło się w poezji?

Napisany kilka lat temu tekst nie dotyczy tylko czasu, w jakim powstał. Jest wspomnieniem wsi sprzed półwiecza, które wkradło się do teraźniejszości i stało się jej częścią. Skomplikowana sytuacja temporalna Gorzkich żali, tak jak i całej twórczości poetyckiej Szewca, wydaje się wynikiem swobodnego stosunku poety do przeszłości i współczesności, ale przede wszystkim przyswojenia kategorii anachronizmu, którą niekiedy utożsamia się z mieszaniem czasów, dowolnym kojarzeniem perspektyw, antycypacją historii bądź retrospektywami umieszczonymi w przyszłości. A zatem także i z Ingoldowskimi kryteriami opisu. Jak pisze Marek Zaleski:

Anachronizm jest uznawany za narzędzie odzyskiwania przeszłości uwięzionej w teraźniejszości, teraźniejszości niekoniecznie zawłaszczanej właśnie przez reżimy władzy i wiedzy. Benjaminowska metafora „wywoływania obrazów przeszłości” jest tu szczególnie może wymowna. Obcujemy z minioną historią niczym z tekstem, rzeczywistość - ta teraźniejsza, albo miniona - zdeponowana jest w tekście w formie obrazów, które można porównać do obrazów potencjalnie istniejących na światłoczułej płytce ${ }^{4}$.

Omówiona pokrótce przez badacza kategoria kojarzy się z tą poezją z wielu powodów. W połowie lat dwutysięcznych, gdy Szewc publikuje zbiór Całkiem prywatnie i zawiesza pisanie powieści, literatura polska mierzy się z problemem konsumpcjonizmu i zaawansowanego kapitalizmu (Fototapeta Michała Witkowskiego), emigracji (Dom Róży Huberta Klimko-Dobrzanieckiego, Powrót Aleksandra Zbigniewa Kruszyńskiego), uchodźstwa oraz wykluczania różnorakich grup społecznych (Skaza Magdaleny Tulli). Sprawa przeszłości i jej reprezentacji staje się jednocześnie o wiele istotniejsza niż wszystkie pozostałe, pojawia się jednak w tak zróżnicowanych językowo i poetologicznie opowieściach (m.in. Andrzeja Barta, Stefana Chwina, Jerzego Ficowskiego, Mikołaja Łozińskiego, Jarosława Marka Rymkiewicza), że nawet dzisiaj ich uporządkowanie i przedstawienie w postaci jednej syntetycznej koncepcji wydaje się trudne.

${ }^{2}$ Osobnego studium wymaga kategoria materiału w poezji Szewca. Celowo nie piszę tu o materialności, bo akurat to pojęcie wzbudza wiele słusznych wątpliwości u Ingolda. Por. Tim Ingold, Materiały a materialność, w Splatać otwarty świat. Architektura, antropologia, design, wybór i opracowanie Ewa Klekot (Kraków: Instytut Architektury, 2018), 5-34.

${ }^{3}$ Ingold, Materiały a materialność, 31.

${ }^{4}$ Marek Zaleski, „Alaryk ante portas, czyli korzyści z anachronizmu”, w Sam poczatek. Lata 1944-1948 w literaturze okresu Polski Ludowej, red. Hanna Gosk, Bożena Karwowska (Warszawa: Elipsa Dom Wydawniczy, 2017), 195. 
O anachroniczności wielu tekstów poetyckich Szewca mogą także świadczyć ich tematy i bohaterowie: przede wszystkim Czołki, wieś położona w gminie Sitno w powiecie zamojskim, wymieniana przez poetę dziesiątki razy, Łabuńka, Czarny Potok, Stabrów, Majdan, Łapiguz; rzeczy codziennego użytku, zwierzęta i rośliny, których nazw się dziś nie pamięta: ciernik, przetak, śnieguliczka, kury leghorny, perlice, fajtak, pójdźka, przylepek pomrocznik, kanarkowy kolor ścian, sagan, listkowiec cytrynek; ludzie znani tylko swoim najbliższym i autorowi: pani Bilowa, pan Kawa, pani Baranowa, stary Kuczyński, Skórkowa; dawno minione wiejskie zwyczaje i rytuały, jak nabożeństwa majowe przy figurze, pasienie krów, sianie własną ręką zboża, dymiące kartofliska, skubanie gęsi, krojenie ziemniaków wiosną, jesienne otwieranie makówek, mierzenie fajtakiem zagonów.

To, co niedawno zakończone, należy jeszcze do mało interesującej, nie dość dobrze przetrawionej i zakonserwowanej przeszłości. Przykładem takiej właśnie przeszłości są opisywane przez Szewca rzeczy, sytuacje i zdarzenia. Nie nadają się na symbole i metafory (ze względu na swój młody wiek i niepozorność ${ }^{5}$, ale też, bardzo często, przez brak związku z tzw. kulturą wysoką czy chłopską „etymologię”), pod wieloma względami nie mogą też konkurować z problematyką wielkomiejskiego świata, nie sposób ich też nazwać istotnymi z punktu widzenia życia społecznego, sztuki czy nauki (jak polityka lub ekonomia) ${ }^{6}$. Z prostego wyliczenia wynika, że opisywane w tej poezji byty są rozsadnikiem wielu nowoczesnych sposobów ujmowania rzeczywistości, w tym także wspomnianego anachronizmu - kategorii wywodzącej się z dualistycznego przeświadczenia o rozdzielnym istnieniu czasów, temporalności i modalności. Wszystko to sprawia, że należałoby je analizować nie za pomocą tradycyjnych pojęć, ale przeciwnie, pojęć nowych, mocno związanych z materiałem poetyckim bądź na jego podstawie wypracowanych, z niego wyjętych.

Tymczasem przywracając operacyjność anachronizmowi, Zaleski umieszcza go w słowniku terminów nowoczesnych i czyni odpowiedzialnym za umacnianie pewnych podziałów i porządków. Celem tego artykułu jest natomiast udowodnienie, że poezja Piotra Szewca nie ma nic wspólnego z kategoriami myślenia zachodniego, na których opiera się modernizm, ale przekracza je w kierunku nowej ontologii zaprzeczającej, z bliżej nieznanych powodów, nowoczesności. Tworzą ją różne, nietrwałe sploty, na potrzeby niniejszego szkicu przedstawione w trzech, być może przesadnie uporządkowanych, grupach: martwe - żywe ${ }^{7}$, teraźniejsze - przeszłe, ludzkie - nieludzkie ${ }^{8}$. Dzięki zaproponowanemu podziałowi i omówieniu wybranych wierszy, należących do wspomnianych porządków, będzie można pokazać, że nowa ontologia nie sprowadza się do prywatnej mitologii funkcjonującej na obrzeżach społeczno-politycznego zaangażowania podmiotu, ale jest całkiem poważną, silną propozycją zanegowania rzeczywistości i zdemontowania większości tworzących ją podziałów, w tym przede wszystkim podziału na to, co ważne tu i teraz oraz przestarzałe.

\footnotetext{
${ }^{5}$ Por. na ten temat: Tomasz Mizerkiewicz, „Twórczość niepozorna i nowa fenomenologia. O wierszach Piotra Szewca”, w Twórczość niepozorna. Szkice o literaturze, red. Joanna Grądziel-Wójcik, Agnieszka Kwiatkowska, Lucyna Marzec (Poznań: Pasaże, 2015), 75-83.

${ }^{6}$ Wiele wierszy Szewca, szczególnie z tomów Całkiem prywatnie i Moje zdanie, to ekfrazy, również one przetwarzają tematykę ściśle związaną z przedstawianiem przyrody oraz krajobrazów podmiejskich i wiejskich przez grafików, m.in. Leszka Rózgę, Leopolda Lewickiego, Barbarę Rosiak, Stanisława Fijałkowskiego, i malarzy (zamieszczona na okładce Światełka akwarela Henryka Wańka).

${ }^{7}$ Antynomia, zapisywana bez myślnika jako „martwe żywe”, występuje w wierszu Dawno nieobecne. Piotr Szewc, „Dawno nieobecne”, w Cienka szyba (Kraków: Wydawnictwo Literackie, 2014), 33.

${ }^{8}$ Nazwy grup, mające charakter opozycji, w istocie oznaczają związek objętych tą nomenklaturą obiektów z pasażami. Z kolei pasaż (fr. passage - przejście) jest rozumiany nie tyle jako opozycyjnie zestawione przymiotniki, ale łącznik, znamionujący ruchomość, a nawet „ślizganie się” znaczenia.
} 
Lubelska wieś lat sześćdziesiątych i siedemdziesiątych może wydawać się nie tylko anachronizmem, ale także backlashem. Próbując wytłumaczyć to trudne do zdefiniowania pojęcie, wprowadzone przez Susan Faludi w pracy Backlash: The Undeclared War Against Women ${ }^{9}$, Piotr Forecki sięgnął po tak różne określenia jak rykoszet, reakcja i - w znaczeniu dosłownym "gwałtowne odrzucenie kolby tuż po wystrzale broni palnej" ${ }^{10}$. Należący do słownika feminizmu, a zatem tradycji obcej Szewcowi, backlash oznacza także „antagonistyczną reakcję, sprzeciw, kontruderzenie wobec zachodzących zmian społecznych oraz pojawiających się postępowych idei"11. Rolę backlashu może odegrać nie tylko określona reakcja społeczna, ale także literatura czy sztuka. Konsekwentnie notowane relacje z życia lubelskiej wsi po roku 2000, a szczególnie rodzinne relacje, przeplatane wspomnieniami, stanowią dla Szewca przywołane „kontruderzenie” - są odpowiedzią na logikę późnego polskiego kapitalizmu, o której raz po raz wspomina w Całkiem prywatnie. Przykładem manifestacji takiego stanowiska może być Ciało obce, wiersz z wplecionym wspomnieniem „gomułkowskiej Polski powiatowej”:

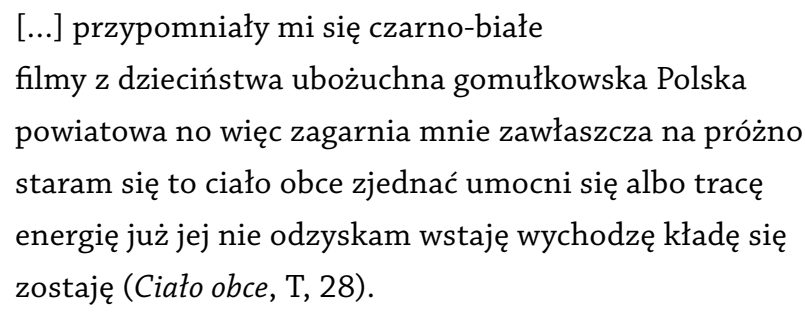

Polska powiatowa to w poezji Szewca nie tylko wiodący temat, to właśnie ów równoznaczny z wystąpieniem czasu z brzegów anachronizm, reakcyjny backlash, wreszcie „nasadka” na rzeczywistość, przy bliższym oglądzie okazująca się nią samą. Jak w Przetartem oczy, gdzie podmiot, spacerując między nowymi domami położonymi na jednej z zamojskich ulic (Spadek), zaczyna w nich rozpoznawać minione:

[...] i znikały nowe domy zajęły miejsce starych inne właśnie się rozpadły w przechodniach chciałem rozpoznać dawnych znajomych pomyślałem o moich (Przetarłem oczy, T, 58).

\section{Sploty}

Rozważając możliwość analizowania poezji Szewca za pomocą kategorii twórczości niepozornej, Tomasz Mizerkiewicz sięgnął po pojęcie obecności Hansa Ulricha Gumbrechta:

[...] specjalny, trochę peryferyjny status twórczości niepozornej bierze się z tego, że należy ona - mówiąc słowami Gumbrechta - do kultury obecności danego czasu. Tworzona jest nie dla zawiązywania relacji logicznych, hierarchizacji, fabularyzacji i interpretacji, które to przykładowo wymienione ak-

\footnotetext{
${ }^{9}$ Susan Faludi, Backlash: The Undeclared War Against Women (New York: Crown Publishing Group, 1991).

${ }^{10}$ Piotr Forecki, Po Jedwabnem. Anatomia pamięci funkcjonalnej (Warszawa: IBL PAN, 2018), 22. Do tego znaczenia może - w przewrotny sposób - nawiązywać ostatnie zdanie wiersza Niewiele czasu: „nagle korkowiec wystrzelił i zrobiło się ciemno”. Cyt. za: Piotr Szewc, „Niewiele czasu”, w Światełko (Kraków: Wydawnictwo Literackie, 2017$), 9$.

${ }^{11}$ Forecki, Po Jedwabnem, 23.
} 
tywności zakładają dystans oraz odnoszenie się do świata widzianego jako gra znaczeń. Swoje zadanie widziałaby raczej w rozpoznaniu tego, jak współistnieją ze sobą pewne zjawiska, tworząc wspólnie coś w zasadzie afabularnego - zbiorowość równorzędnych obiektów postrzeganych jako obecne ${ }^{12}$.

W rozpoznawaniu afabularnych zestawień obiektów równorzędnych Mizerkiewicz jest pionierem - poezja Szewca okazuje się bowiem zbiorem splotów i ciągów, pełnych wspomnień, zmyśleń, przekręceń rzeczywistości, ale i bardzo dokładnie zapamiętanych faktów. O tym koncepcie, choć zdaje się on narzucający, w odniesieniu do twórczości poetyckiej autora Światełka wcześniej nikt nie pisał. Skądinąd wyjaśnianie jej za pomocą tych samych narzędzi, jakie krytyka stosowała do prozy autora Zagłady, a więc przede wszystkim kategorii małych ojczyzn i mitografii, nie ma większego sensu nie tylko dlatego, że zakres problemów podejmowanych przez poetę w zbiorach Całkiem prywatnie, Moje zdanie, Cienka szyba i Światełko jest szerszy niż wspomniane pojęcia ${ }^{13}$. Nie ma ono sensu także dlatego, że stabilna rzeczywistość Zamościa, znana z trylogii powieściowej, uległa tu złamaniu, przetarciu i rozkruszeniu, w efekcie stając się zbiorowiskiem różnych drobin, zagmatwanych ontologicznie bytów, niejasnych dyskursów, nieusystematyzowanej wiedzy. Znaleźć w nim można duchy zmarłych, na wpół żywe postacie, zjawy, mary senne, stare, bezużyteczne przedmioty, miejsca trudne do lokalizacji na mapie, powyrywane z atlasów i życiorysów bohaterów, słowem - szereg informacji niedających się w żaden prosty sposób uporządkować ani wykorzystać. W innym miejscu Mizerkiewicz porównuje ten stan rzeczy do „płynności” i „wędrówki”, mówi o poluzowaniu więzów między obiektami, a wreszcie o zmianie przestrzeni życia ludzkiego podmiotu z ziemskiej na powietrzną ${ }^{14}$.

Poezja Szewca wydaje się laboratorium ontologii nienowoczesności, miejscem, gdzie dochodzi do usunięcia sztucznie narzuconych przez nowoczesność podziałów na władzę i wiedzę, technikę i naturę, oraz zawiązania nowych sojuszy. Za Brunonem Latourem można nazywać ten sposób budowania relacji „zrzeszaniem” (fr. rassembler). Wyraża się on m.in. w porównywaniu „definiowania (lub niedefiniowania) materii, prawa, świadomości, duszy zwierząt bez przyjmowania za pewnik ustaleń nowoczesnej metafizyki” ${ }^{15}$. Dlatego też kategoria kultury obecności, wyjaśniana przez Mizerkiewicza z jednej strony jako dialektyka odkrytego i zakrytego, z drugiej jako pewna właściwość formalna tekstów Szewca, warta jest uzupełnienia o możliwości, które stwarza dla interpretacji tej poezji pojęcie nienowoczesności, zaprojektowane w odruchu zwątpienia w doskonałą ideę modernizmu oraz pod wpływem kryzysu środowiska i ekonomii, do którego doprowadził zachodni kapitalizm, po 1989 roku coraz silniej obecny także i w Polsce powiatowej ${ }^{16}$.

\footnotetext{
${ }^{12}$ Mizerkiewicz, Twórczość niepozorna, 78.

${ }^{13} \mathrm{Na}$ temat kategorii „małej ojczyzny” i jej upolitycznienia, którego zakładnikiem stała się, zdaniem Krzysztofa Uniłowskiego, także proza Szewca, por. Krzysztof Uniłowski, „Do czego liberałom potrzebne «małe ojczyzny»?”, FAart., nr 3-4 (2003): 132-139. Por. także: Jarosław Borowski, „Smak prowincjonalnej magdalenki. Zamość, którego nie ma w prozie. Piotra Szewca", w Literackie twarze Zamojszczyzny (Zamość: Wydawnictwo Państwowej Wyższej Szkoły Zawodowej w Zamościu, 2009); Wacław Pyczek, „ «Jadę do Zamościa». Geografia poetycka Piotra Szewca”, w Literackie twarze Zamojszczyzny (Zamość: Wydawnictwo Państwowej Wyższej Szkoły Zawodowej w Zamościu, 2009); Agnieszka Nęcka, „Drobiazgi życiu wyrwane. O poezji Piotra Szewca”, w: Literatura i obiekt/yw(izm), red. Barbara Gutkowska, Agnieszka Nęcka (Katowice: Oficyna Wydawnicza Wacław Walasek, 2014); Artur Daniel Liskowacki, „Martwe żywe. O poezji Piotra Szewca”, Elewator nr 2 (2016); P. Mackiewicz,Tymczasem. Tutaj”, w Szewc, Tymczasem.

${ }^{14}$ Tomasz Mizerkiewicz, „Przestrzenne czytanie wierszy Piotra Szewca”, Nowe Książki, nr 12 (2019).

${ }^{15}$ Bruno Latour, Nigdy nie byliśmy nowocześni. Studium z antropologii symetrycznej, tłum. Maciej Gdula (Warszawa: Oficyna Naukowa, 2011), 27.

${ }^{16}$ Latour, Nigdy nie byliśmy nowocześni, 19.
} 
Koncepcję nienowoczesności, której podstawy rozpatrywane będą dalej, należy rozumieć dosłownie. Technologia, będąca istotnym tematem wierszy Szewca, opiera się na prostych, przestarzałych dziś rozwiązaniach i dotyczy przede wszystkim rolnictwa. Jej pośrednikiem (materialnym nośnikiem) jest dziadek. Jak w Kształcie chwilowym:

Początek wakacji dziadek klepie kosę Czołki dźwięczą miarowo

dochodzi południe po krzakach kury sennie gdaczą... (Kształt chwilowy, T, 52)

Albo w wierszu Jak źdźbło:

[...] jechaliśmy koleinami przez Sitno żółte motyle trzepotały las pachniał zbierałem jeżyny leć do nieba bo stąd bliżej dziadek woła z furmanki (Jak źdźbło, T, 49).

Bohaterką wielu wspomnień Czołek pozostaje także babcia. Zwykle Szewc opisuje jej pracę w polu w huku ciągnika i snopowiązałki: „Piotrusiu mówi zrób powrósło zwiąż to” (Zwiąż to, $\mathrm{T}, 38)$.

W innym wierszu z Mojego zdania rzeczywistość jawi się jak stodoła, w której zamknięto niszczejące narzędzia:

[...] na klepisku koło ciągnika odcisnęło ślad ale on tylko

tymczasem gdzieżbyś nie pamiętała ciepło ubrani bo

listopad lub grudzień nad wanną nożem otwieraliśmy

makówki strasznie mnie to nudziło nogi cierpły zmierzch (Tylko tymczasem, T, 55).

Bądź jak dom z Tak trzeba:

Drogą którą jeździł kiedyś drabiniasty wóz muszę się przeciskać

tyle tu wszystkiego niepotrzebnego

dom zamknięty na kłódkę pusta obora w komórce rdzewieją motyki (Tak trzeba, T, 61).

Istotne wydaje się nie tylko to, że Szewc opisuje przestarzałe narzędzia rolnicze, ale także to, że zamiast zmodernizowanej technologii pokazuje proces zniszczenia. Wycina w ten sposób z opowieści czas transformacji, ale i okres upadku wsi pegeerowskiej oraz jej przemian po 1989 roku. Można się zastanawiać nad celowością tego zabiegu. Nie chodzi w nim przecież ani o uwznioślenie najczęściej ciężkiej pracy ludzkiej i dość prymitywnych narzędzi, ani o podkreślanie jej wyczerpującego charakteru. O niewygodach Szewc pisze wymijająco i zdawkowo, powtarzając język, jakim mówi się o nich do dziecka, nie chcąc go zbytnio przerazić. Z wiersza Zwiąż to, poświęconego zbiorom pszenicy: „konopny sznurek rani dłonie koniki polne skaczą” (Zwiąż to, T, 38).

Wyeliminowanie postępu technicznego z opisu życia powojennej lubelskiej wsi oznacza więc przede wszystkim odejście od koncepcji czasu jako nieodwracalnej osi oraz idei kapitalizacji, i jednocześnie porzucenie nowoczesnego magazynowania i muzealizacji przeszłości. Ma także znamiona archaizacji - zjawiska towarzyszącego postępowi, które dla nowoczesnych, jak twierdzi Latour, oznacza powrót wypartego, z którym zidentyfikowano przeszłość, utwier- 
dzając się w przekonaniu, że da się nad nią zapanować. W poezji Szewca archaiczne wyparte nie przeraża, czas nie płynie, a namnażanie się wspomnień nie oznacza ich inwazji, ale - jak dowodził Mizerkiewicz - „zbiorowość równorzędnych obiektów postrzeganych jako obecne” ${ }^{17}$. Poeta kończy z iluzją następstwa czasów, tak charakterystyczną dla nowoczesności. Jego bohater, jadąc z dziadkiem i mamą furmanką, nagle nieruchomieje (w sensie czasoprzestrzennym) i wyrzuca z siebie słowa wiersza: „stanęliśmy koń opuszcza głowę pasie się już ponad czterdzieści lat czeka aż ruszymy" (Jak źdźbło, T, 49). W wierszach Szewca to, co od wieków rozdzielane w kulturze, staje się płynną, trudną w opisie masą. Uwidacznia to zakończenie $\mathrm{Na}$ rowerze ze Światełka:

\section{[...] wyrzucić sprawy mieszają się ucierają oddzielają koła jeszcze się kręcą muszę czekać aż teraźniejszość rozleje się jak coraz mniej wyraźna plama ${ }^{18}$.}

Można zaryzykować tezę, że wszędzie tam, gdzie Szewc pisze o czasie w sposób daleki od tradycji kultury Zachodu (przypomnijmy, że tych wypowiedzi, jak wielu innych, nie traktuje się tutaj jako metafory. W przeciwnym razie rozumienie czasu jako figury pewnej rewolucji kulturowej z pewnością należałoby zmienić), formułuje wnioski bliskie koncepcji nienowoczesności w znaczeniu Latoura. Fragment pracy Nigdy nie byliśmy nowocześni nieco na wyrost oddaje tę intuicję:

Perspektywa retrospektywna nazywana przeze mnie nienowoczesną (amodernistyczną) zamiast demaskować, przegrupowuje, denuncjację zastępuje brataniem, rozdziela, a nie podważa. Nienowoczesny jest każdy, kto bierze pod uwagę i Konstytucję nowoczesnych, i populację hybryd. Które ta konstytucja odrzuca (przyczyniając się zarazem do ich rozprzestrzeniania) ${ }^{19}$.

Koncepcja nienowoczesności dochodzi w poezji Szewca do głosu jeszcze wyraźniej w dwu spośród trzech wymienionych splotów. Pierwszy tworzą relacje ludzi ze zmarłymi, drugi związki ze zwierzętami. Źródłem obu - tak jak spiralnie, a nie liniowo rozumianego czasu - jest unieruchomiona we wspomnieniu pochodzącym z drugiej połowy XX wieku polska kultura chłopska. Obcowanie z duchami, należące do głównych tematów Cienkiej szyby i Światełka, przeradza się jednak u Szewca w coś więcej niż wiejskie wierzenie oparte na katolickich rytuałach (w rodzaju majowego czy pogrzebowych modlitw). Podobnie jak ruchy czasu uobecnianie się zjaw nie budzi w podmiocie strachu, zwątpienia, zdziwienia i żadnej troski. Jest dokładnie takie, jakie powinno być. Zdarza się, jakby nic innego nie wydarzyło się wówczas na świecie. Przypomina to uwagi poczynione wyżej w związku z wierszem Gorzkie żale, wywołującym ten sam co i tutaj afekt zobojętnienia przy równoczesnej zgodzie na oczekiwany stan rzeczy. Szewc stwierdza to mimochodem, jak w Bukieciku z Cienkiej szyby, gdzie jedynym dowodem na to, że podmiot ma przed sobą ducha (czyli panią Stasię, która wpadła na chwilę do babci), jest krótkie: „dziwne bo przecież od dawna leży obok mamy” (Bukiecik, T, 50).

\footnotetext{
${ }^{17}$ Mizerkiewicz, Twórczość niepozorna, 78.

${ }^{18}$ Piotr Szewc, Na rowerze, w Światełko, 11.

${ }^{19}$ Latour, Nigdy nie byliśmy nowocześni, 71.
} 
Być może najistotniejsze w postrzeganiu splotu żywe-martwe pozostaje stwierdzenie, że nie przynależy ono do żadnej transcendencji, nie wynika z wiary w cokolwiek, nie ma też charakteru religijnego. Naturalnym kontekstem dla tych rozważań jest wcześniej wspomniany katolicyzm, ale podobnie jak czas, tak i zadeklarowana wiara w Boga nie mieści się w poezji Szewca w żadnych sztywnych ramach, jest doświadczana przez podmiot jak wszystko inne pod wpływem jemu tylko znanych decyzji. Proces doświadczania nieobecnego przypomina sięganie ręką po obecne i w tym sensie ma raczej charakter gestu Gumbrechtowskiego, a nie Latourowskiego; to, co obecne, „winno być możliwe do dotknięcia ludzkimi dłońmi” ${ }^{20}$.

Sugestywnie o doświadczaniu obecności nieobecnego pisze Szewc w tytułowym wierszu ze zbioru Cienka szyba, gdzie swoich bliskich zmarłych - „babcię mamę dziadka ojca Lutka Jacka” porównuje do gołębi, które „zleciały się na parapet”"22, a medium, oddzielające żywych od zmarłych, nazywa „cienką szybą"23. Szczególnie istotna wydaje się uwaga o sposobie, w jaki zmarli zjawiają się w życiu podmiotu, razem i osobno („siedzieliście razem i każde osobno”24), co oznacza właśnie ową Latourowską hybrydowość, niezdecydowanie, niekonkluzywność bytu, jednoczesność. Tę samą myśl Szewc powtarza w tytułowym w wierszu kolejnego zbioru - Światełku:

Jedni obok siebie inni osobno babciu
twoja duża kołdra zbyt mała żeby nas
okryć $[. . .]^{25}$.

Koncepcja razem-osobno po raz pierwszy pojawia się w tomie Cienka szyba, w wierszu Wszystko osobno, jednak nie dotyczy splotów życia i śmierci, ale upływu czasu: niszczenia domu babci, mieszkania podmiotu, sypiącego się styropianu. Materialna nietrwałość staje się też początkiem refleksji nad koniecznością przekroczenia modernistycznych podziałów i wymyślenia ontologii, która z jednej strony pozwalałaby je zdemontować, a z drugiej pokazać jako „zrzeszenie” pojedynczych bytów. Jeśli przyjrzeć się z tej perspektywy Wielkiej szpuli, okaże się, że w myśleniu Szewca „sklejalne" $i$ „zestawialne” może być to wszystko, co zwykle uważa się za niedopasowane, rozdzielne i niespójne: „jedno się klei drugie strzępi trzecie urywa” (Wielka szpula, T, 115).

\section{Propozycje i wnioski}

Powyższe omówienie pozwala ze sobą zestawić koncepcje Szewca i jeszcze jeden projekt krytycznie nastawiony wobec nowoczesności: teorię nowego animizmu izraelskiej antropolożki Nurit Bird-David, która w pracy Us, Relatives. Scaling and Plural Life in Forager World ${ }^{26}$ wprowa-

\footnotetext{
${ }^{20}$ Hans Ulrich Gumbrecht, Produkcja obecności. Czego znaczenie nie może przekazać, tłum. Krzysztof Hoffman, Weronika Szwebs (Poznań: Wydawnictwo Naukowe UAM, 2016), 23.

${ }^{21}$ Piotr Szewc, „Cienka szyba”, w Cienka szyba (Kraków: Wydawnictwo Literackie, 2014), 34.

${ }^{22}$ Szewc, Cienka szyba.

${ }^{23}$ Szewc, Cienka szyba.

${ }^{24}$ Szewc, Cienka szyba.

${ }^{25}$ Piotr Szewc, „Światełko”, w Światełko, 43.

${ }^{26}$ Nurit Bird-David, Us, Relatives. Scaling and Plural Life in Forager World (California: University of California press, 2017).
} 
dziła kategorię mnogiego życia (plural life), opierając się m.in. na ustaleniach Latoura. Nie wdając się w szczegóły jej pracy, a wypunktowując jedynie najważniejsze kwestie, takie jak przedefiniowanie osoby i człowieczeństwa (personhood), istot innych niż ludzie (other-than-humans, nonhumans, spirits) czy wreszcie uczynienie kategorią najistotniejszą w tych studiach relacji (relatives), warto zaproponować namysł nad społecznością widzianą w małej skali, taką jak badane przez Nurit-Bird społeczności południowych Indii, w odniesieniu do omawianej poezji.

Opisywane przez Szewca środowisko najbliższych składa się, tak jak społeczności w rodzaju Nayaka, z krewnych, są nimi jednak nie tylko żywi ludzie, ale też zwierzęta pozostające z nimi w zmiennych stosunkach (devaru). Odchodząc od tradycyjnie uprawianej etnografii, w tym zwłaszcza od klasycznej teorii animizmu ${ }^{27}$, Nurit-Bird diagnozuje kryzys współczesnych społeczeństw zachodnich spowodowany m.in. roztopieniem się kategorii opisujących niewielkie społeczności w kategoriach globalnych, takich jak naród czy państwo. Sposobem ocalenia postępującego stapiania się mikrozjawisk jest opracowanie pewnych modeli działań i zachowań, które mogą stać się wzorem na przyszłość. To także pomysł Latoura, w podobny sposób czytającego Philippe’a Descolę ${ }^{28}$. Modelem, dającym się opisać na podstawie poezji Szewca, jest opowieść o pewnej rodzinie, zamieszkującej Lubelszczyznę co najmniej od czasów wojny. Widzimy ją w latach sześćdziesiątych i siedemdziesiątych, przypadających na dzieciństwo i młodość głównego bohatera, nazywanego niekiedy Piotrem, by można go było bez większych oporów zestawić z Piotrem Szewcem. Głównymi protagonistami tej opowieści są jego dziadkowie i matka, jej rodzeństwo, siostra, kuzyni, sąsiedzi i sąsiadki. Na tym jednak zbiorowość krewnych się nie kończy. Należą do niej także zwierzęta, jak pies Cygan, rośliny jak tasznik, miejsca i przedmioty jak brama czy studnia. Dalej obserwujemy, jak jeden z członków wspólnoty, wspomniany Piotr, opuszcza ją, ale za pomocą różnych mediacji ze światem zewnętrznym próbuje do niej wracać, m.in. w postaci ptaka. Brzmi to może i osobliwie, jeśli jednak przeanalizuje się trop człowieka-ptaka w tej poezji, okaże się, że nie tradycja chrześcijańska wraz z jej reprezentacją duszy ludzkiej, ale właśnie animizm stanowi poręczną teorią umożliwiającą zrozumienie myśli Szewca.

Począwszy od Całkiem prywatnie, poeta poddaje wnikliwej obserwacji właśnie ptaki. W Szarych piórach namyśla się nad ich martwymi ciałami (rozjechany przez auto gołąb), w Srokach za oknem powraca do stereotypu ptaka-złodzieja, ale dopiero w inspirowanej grafiką Leszka Rózgi Licznej rodzinie wyraża pragnienie wejścia do wspólnoty daszek które realizował będzie w obrębie różnych gatunków w zasadzie we wszystkich kolejnych tomikach. Przypomnijmy jedynie Gawrony przyleciaty z Cienkiej szyby czy Kuropatwy ze Światełka, gdzie ptakami są zmarli sąsiedzi. Albo wiersz [Spoza czasu zasypanego śniegiem] z tego samego zbioru, w którym głosem warszawskiej kawki przemawia nieżyjąca matka. Zmarli krewni od dawna są częścią ziemi, roślin, powietrza. Wiara w to, że nie należy ich szukać na cmentarzu, towarzyszy Szewcowi nieustannie, chociażby w dwuwierszu Jak chryzantema:

W październikowej mgle korona drzewa żółci się jak wielka chryzantema wiatr rozgarnia liście rozdmuchuję płatki tam was szukam ${ }^{29}$.

\footnotetext{
${ }^{27}$ Bird-David, Us, Relatives, 154-155.

${ }^{28}$ Latour, Nigdy nie byliśmy, 64.

${ }^{29}$ Piotr Szewc, „Jak chryzantema”, w Cienka szyba, 41.
} 
Jednocześnie on sam, podmiot tych wierszy, przestaje ufać ludzkiej kondycji i staje się kimś innym niż tylko człowiek: „obstąpiło mnie stadko wróbli nie miałem ani/ okrucha poczułem się że jestem jednym z nich" ${ }^{30}$. Ale i pokrewieństwo z ptakami nie stabilizuje tej hybrydycznej natury. W dwu ostatnich wierszach z tomu Światełka, [Zagnieździłbym się] i [Płatkiem śniegu być] podmiot staje się po prostu częścią atmosfery, powietrzem, cząstką pogody i tak idealnie wtapia się w otoczenie, że znika. Gdyby miało się pewność co do głoszonej przez Szewca filozofii i jej umocowania w katolicyzmie, można by powiedzieć, że podmiot rozpływa się w pustce własnej samotności, nieukojonej po śmierci najbliższych. Ale tak nie jest. Odkrywszy, że i oni są częścią wspólnoty nonhuman kins (Bird-David), Szewc nie opisuje samobójczych marzeń. Przypieczętowuje tym gestem - jak zostało powiedziane - swoją koncepcję ontologii nienowoczesności, która może być traktowana jako alternatywa wobec współczesnego rozpadu świata, ale i sposób podmiotu na pogodzenie się z problemami, które w kulturze Zachodu nie mają właściwych formuł łagodzących bądź skutecznych sposobów radzenia sobie z nimi. Mowa o chorobach i śmierci rodziny, towarzyszącej temu otępiającej pustce, żałobie, odizolowaniu od społeczeństwa przeradzającym się w egoizm i inne zachowania niesłużące dobru wspólnemu. W inspirowanej nowym animizmem ${ }^{31}$ ontologii nienowoczesności wspomniane stany stają się natomiast czymś nieostatecznym, odwracalnym, zawierają sposobność, by cofnąć czas i wejść w kontakt z tym, co jeszcze się nie stało. Pozorny brak logiki, sprawiający wrażenie swobody myślowej lub interpretacyjnej dezynwoltury, wynika tu jedynie z konieczności zaradzenia najpilniejszym (nie tylko) ludzkim problemom, które - gdy się je powierzy przyrodzie, odniesie do historii, odroczy w czasie - stają się, mogą stać się, do wytrzymania.

Szczególną rolę w tych decyzjach odgrywa opis. Odsyłając do tego, co w sztuce statyczne, anachroniczne, pozbawione życia, opis w poezji Szewca jednocześnie stanowi postać skomplikowanego opowiadania historii, nadawania rzeczom ruchu, ich fluktuacji, przemieszczania się w czasie. Staje się też okazją do tego, by wyliczać powszednie, niepozorne, niewyszukane materiały, przechodzi często w formę listy, nieomal wyliczenie. Ponieważ poezja Szewca w wielu miejscach przypomina stawianie fundamentów, opis stanowi w niej formę podstawowej wypowiedzi o charakterze ontologicznym, jest formą przeglądu - już nie bytów, a istnień, i to niekoniecznie tylko tych żywych.

\footnotetext{
${ }^{30}$ Piotr Szewc, „Jeden z nich”, w Moje zdanie (Kraków: Wydawnictwo Literackie, 2009), 5.

${ }^{31}$ Por. Anselm Franke, „Much Trouble in the Transportation of Souls, or: The Sudden Disorganization of Boundaries", w Animism. Volume 1, red. Anselm Franke (Berlin - Oslo - Antwerp: Sternberg Press, 2010), 11-53.
} 


\section{Bibliografia}

Szewc, Piotr. Cienka szyba. Kraków: Wydawnictwo Literackie, 2014.

Moje zdanie. Kraków: Wydawnictwo Literackie, 2009.

Światełko. Kraków: Wydawnictwo Literackie, 2017.

Tymczasem. Wybór wierszy. Poznań: Wydawnictwo WBPiCAK, 2019.

Bird-David, Nurit. Us, Relatives. Scaling and Plural Life in Forager World. California: University of California press, 2017.

Borowski, Jarosław. „Smak prowincjonalnej magdalenki. Zamość, którego nie ma w prozie. Piotra Szewca”. W Literackie twarze Zamojszczyzny. Redakcja Henryk Duda, Edward Fiała, Maria Gorlińska. Zamość: Wydawnictwo Państwowej Wyższej Szkoły Zawodowej w Zamościu, 2009.

Faludi, Susan. Backlash: The Undeclared War Against Women. New York: Crown Publishing Group, 1991.

Forecki, Piotr. Po Jedwabnem. Anatomia pamięci funkcjonalnej. Warszawa: IBL PAN, 2018.

Franke, Anselm. „Much Trouble in the Transportation of Souls, or: The Sudden Disorganization of Boundaries". W Animism. Volume 1. Redakcja Anselm Franke. Berlin Oslo - Antwerp: Sternberg Press, 2010.

Gumbrecht, Hans Ulrich. Produkcja obecności. Czego znaczenie nie może przekazać. Tłumaczenie Krzysztof Hoffman, Weronika Szwebs. Poznań: Wydawnictwo Naukowe UAM, 2016.

Ingold, Tim. „Materiały a materialność”. W Splatać otwarty świat. Architektura, antropologia, design. Wybór i opracowanie Ewa Klekot. Kraków: Instytut Architektury, 2018.
Latour, Bruno. Nigdy nie byliśmy nowocześni. Studium $z$ antropologii symetrycznej. Tłumaczenie Maciej Gdula, Warszawa: Oficyna Naukowa, 2011.

Liskowacki, Artur Daniel. „Martwe żywe. O poezji Piotra Szewca". Elewator nr 2 (2016).

Mackiewicz, P. „Tymczasem. Tutaj”. W Piotr Szewc. Tymczasem. Wybór wierszy. Poznań: Wydawnictwo WBPiCAK, 2019

Mizerkiewicz, Tomasz. „Przestrzenne czytanie wierszy Piotra Szewca”. Nowe Ksiqziki, nr 12 (2019).

———. „Twórczość niepozorna i nowa fenomenologia. O wierszach Piotra Szewca”. W Twórczość niepozorna. Szkice o literaturze. Redakcja Joanna Grądziel-Wójcik, Agnieszka Kwiatkowska, Lucyna Marzec. Poznań: Pasaże, 2015.

Nęcka, Agnieszka. „Drobiazgi życiu wyrwane. O poezji Piotra Szewca”. W: Literatura i obiekt/ yw(izm). Redakcja Barbara Gutkowska, Agnieszka Nęcka. Katowice: Oficyna Wydawnicza Wacław Walasek, 2014.

Pyczek, Wacław. „ «Jadę do Zamościa». Geografia poetycka Piotra Szewca". W Literackie twarze Zamojszczyzny. Zamość: Wydawnictwo Państwowej Wyższej Szkoły Zawodowej w Zamościu, 2009.

Uniłowski, Krzysztof. „Do czego liberałom potrzebne «małe ojczyzny»?", FA-art, nr 3-4 (2003): 132-139.

Zaleski, Marek. „Alaryk ante portas, czyli korzyści z anachronizmu". W Sam poczq̨tek. Lata 1944-1948 w literaturze okresu Polski Ludowej. Redakcja Hanna Gosk, Bożena Karwowska. Warszawa: Elipsa Dom Wydawniczy, 2017. 


\title{
SŁOWA KLUCZOWE:
}

\author{
o n t o log i a
}

NIE N O WOCZESNOŚć

wi eś

$p+a k i$

\section{PRZESZŁość}

\section{ABSTRAKT:}

Nawiązując do teorii Hansa Ulricha Gumbrechta, Brunona Latoura i Nurit Bird-David, autorka próbuje dowieść, że poezji Piotra Szewca towarzyszy koncepcja kwestionująca logikę współczesnego świata oparta na postępie technicznym i wyizolowanym, egocentrycznym podmiocie. Wspomniana koncepcja to ontologia nienowoczesności. Bezpośrednią inspiracją dla niej pozostaje pojęcie nienowoczesności (anowoczesności) Latoura uzupełnione o refleksję nad nowym animizmem Bird-David. Analiza obejmuje cztery tomy poetyckie, wydane w latach 2006-2017, oraz wybór wierszy Szewca z 2019 roku.

\section{Nota O AUTORCE:}

Marta Tomczok (1980) - dr hab., adiunkt na Wydziale Filologicznym Uniwersytetu Śląskiego w Katowicach. Autorka książek: Trofea wyobraźni. O prozie Leo Lipskiego (2011), Metonimie Zagłady. O polskiej prozie lat 1987-2012 (2013), Czyja dzisiaj jest Zagłada? Retoryka - ideologia popkultura (2017), Czy Polacy i Żydzi nienawidzq się nawzajem? Literatura jako mediacja (2019). Interesuje się wpływem nowych metodologii na studia o Zagładzie i innych ludobójstwach, refleksją krytyczną nad estetykami uznanymi za minione (postmodernizm), nowym animizmem oraz historią środowiskową węgla. 